\title{
MEANING OF CHILD PSYCHOLOGY WITH REFERENCE TO LITERARY WORKS OF RUSKIN BOND
}

\author{
Dr.Ravindra Kumar ${ }^{1}$ (Ph.D., NET) \\ (Professor. English Department) \\ C.C.S University, Meerut \\ Aakanksha Tyagi ${ }^{2}$ (M.Phil-English) \\ C.C.S University, Meerut
}

\begin{abstract}
Ruskin Bond is taken into account to be a pioneer of children's literature in India. Since Bond liked his boyhood considerably, all his children's stories, whether autobiographical or semiautobiographical, express his looking for a happy childhood. In this context, the study of child psychology becomes much more relevant and important.
\end{abstract}

Child psychology is indeed a very deep and interesting subject to study. The children are the most creative beings and most natural in their thinking. They live in their own 'dreamy' world of their own. They fantasize and spin stories on their own creating a beautiful, enchanting world of their dreams. Bond is one of the most prolific writers who has written abundantly on children. He is one of the celebrated writers writing for children. The author has studied the stories of Ruskin Bond concerning child psychology. Ruskin Bond (born 19 May 1934) is an Indian author of British descent. He lives together with his adopted family in Landour, in Mussoorie, India. The Indian Council for Child Education has recognized its role in the growth of children's literature in India. He was felicitated with the prestigious Sahitya Academy Award in 1992 for his book 'Our
Trees Still Grow in Dehra'. He was awarded the reputed Padma Shri in 1999 and Padma Bhushan in 2014.

Ruskin Bond was born on 19 May 1934 during a hospital, to Edith Clarke and Aubrey Bond, in Kasauli. His siblings were Ellen and William. Ruskin's father was with the Royal Air Force from 1939 till 1944. When Bond was eight years old, his mother separated from his father and married a Punjabi Hindu, Hari. Unfortunately, Ruskin lost his father at the tender age of ten which left a permanent vacuum in his life. His sister Ellen lived in Ludhiana until she died in 2014.

Keywords: Child psychology \& filmography

\section{Introduction}

Bond spent his infancy in Jamnagar (Gujarat) and Shimla. At the age of ten, Ruskin visited live at his grandmother's house in Dehradun after his father's death that year from jaundice. Ruskin was raised by his mother and stepfather. He did his schooling at Bishop Cotton School in Shimla, from where he graduated in 1950 after winning several writing competitions 
International Journal of Trends in English Language and Literature (IJTELL) An International Peer-Reviewed English Journal; Volume-2, Issue-3; 2021 $\underline{\text { www.ijtell.com }}$ Impact Factor: 5.144(SJIF)

ISSN: $2582-8487$

within the school including the Irwin Divinity Prize and the Hailey Literature Prize. He wrote one of his first short stories, 'Untouchable', at the age of sixteen in 1951. He visited his aunt's place within the Channel Islands (U.K.) in 1951 for better prospects of a job and stayed there for two years but he constantly kept missing India dearly in London and consequently returned to India - his real 'home'. He started writing his first novel, 'The Room on the Roof'- the semiautobiographical story of the orphaned Anglo-Indian boy named Rusty; the novel bearing many similarities with Ruskin's personal life. It won the toilet Llewellyn Rhys Prize, (1957) awarded to a British Commonwealth writer under 30 . He again moved to London and worked in a photo studio while searching for a publisher for the novel to be published. After getting it published, Bond used the advance money to pay the sea passage to Bombay and finally settle in Dehradun- the city where his heart and soul lie.

\section{Ruskin Bond and Children's Stories}

Ruskin Bond may be a documented Indian Writer in English. He has written quite a hundred short stories, six novels, three collections of verse and over thirty books for youngsters as Times stops at Shamli, Angry River, Road to Bazaar, Rain in the Mountains, Cherry Tree, Great Stories for Children, Vagrants in the Valley, etc. For the last sixty years, the typewriter of Ruskin Bond has been continuously clicking and creating masterpieces and has been writing for the last sixty years in different genres of literature.

\section{Ruskin Bond - a milestone in Childres's Literature in India}

His stories and novels got worldwide publicity and acclaim. In India, his novels and stories caught the Directors' attention and some of his novels like 'A Flight of Pigeons', 'Suzzana's Seven Husbands', 'The Blue Umbrella' have been put on celluloid. To brief; Filmographythe 1978 Bollywood film 'Junoon' is based on Bond's historical novella 'A Flight of Pigeons' (about an episode during the Indian Rebellion of 1857). It was produced by Shashi Kapoor and directed by Shyam Benegal. The Rusty stories are adapted into a Doordarshan TV series 'Ek Tha Rusty'. He was also awarded various prizes and awards at the national level. Several stories of Bond are incorporated within the school curriculum in India, including 'The Night Train at Deoli', 'Time Stops at Shamli' and 'Our Trees Still Grow' in Dehra. In 2005, the Bollywood director Vishal Bhardwaj made a movie that supported his popular novel for youngsters, 'The Blue Umbrella'. The movie won the National Award for Best Children's film. Ruskin Bond made his maiden big-screen appearance with a cameo in Vishal Bhardwaj's film '7 Khoon Maaf' in 2011, supported his story 'Susanna's Seven Husbands'. Bond appears as a Bishop in the movie with Priyanka Chopra playing the title role. Bond had earlier collaborated with Bharadwaj in 'The Blue Umbrella' which was also based on one of his works.

\section{Study of Child Psychology}

Developmental psychology is the scientific study of how and why human beings change their attitude, behavior, 
pattern, life. Originally concerned with infants and youngsters, the sector has expanded to incorporate adolescence, adult development, aging, and therefore the entire lifespan. Developmental psychologists aim to elucidate how thinking, feeling, and behavior change throughout life. This field examines change across three major dimensions: physical development, cognitive development, and socio-emotional development. Within these three dimensions are a broad range of topics including motor skills, executive functions, moral understanding, language acquisition, social change, personality, emotional development, self-concept, and identity formation.

1. Early Adolescence: 9 to 13 years (preteen),

2. Mid Adolescence: 13 to fifteen years and

3. Late Adolescence: 15 to 18 years

\section{Importance of Study of Child's Psychology}

1. To know the child in a better manner.

2. To know the skills of the child and positively develop them.

3. to seek out the dislikes of the kid.

4. To identify the strengths of the child at a young age.

5. To teach the best things in life to children through morals and stories.

6. To understand behavioral problems in the child.

\section{Issues Faced by Today's Children}

1. Lack of Guidance, Support, and Motivation from parents.

2. School Pressure ad peer pressure.

3. Expectations from family and society.
4. Biological Changes in their bodies.

5. Emotional Imbalance.

6. Family Conflicts and illness problems.

7. Misunderstanding with parents.

8. Anger, ego, and stress-related problems.

\section{Solutions to Above Issues}

1.The Children require a healthy environment in the family so parents should be happy and healthy themselves first.

2. Faith and better understanding between parents and child.

3. Reducing School Pressure.

4. Proper guidance to the children

5. All-round development by identifying the talents of the kid and motivating them.

6. Channelizing the skills of the child positively towards constructive things in life

\section{Ruskin Bond's Stories and Child's Psychology.}

Ruskin Bond has very efficiently portrayed and weaved the child's behavior and expectations in his short stories. If they are seriously read by the young children they will get a better understanding of the problems and consequently, the parents will be benefitted in the long run. The stories are grasping and are widely accepted and read.

\section{Conclusion}

The Paper is a decent contribution to the child's psychology and how we can relate the stories of Ruskin bond with this important issue of the children. The stories can be the best way to educate the children on major issues faced at this young age. The world of children is different from the adults. The children are more imaginative, 
International Journal of Trends in English Language and Literature (IJTELL)

An International Peer-Reviewed English Journal; Volume-2, Issue-3; 2021

creative, and most natural in behavior. These qualities when utilized in the best way they can become better citizens of the world.

\section{References}

Bond, Ruskin. The Best of Ruskin Bond, 'My Father's Trees in Dehra', New
Delhi: Penguin Books India Pvt. Ltd., 1994,

Bond, Ruskin, Tiger. Tiger Burning Bright. Panther's Moon and Other Stories, New Delhi: Penguin Books India Pvt. Ltd., 1994, 34-38.

Bond, Ruskin. The Night Train at Deoli. 